IRA-International Journal of Education \& Multidisciplinary Studies ISSN 2455-2526; Vol.06, Issue 03 (2017)

Pg. no. 218-230

Institute of Research Advances

https://research-advances.org/index.php/IJEMS

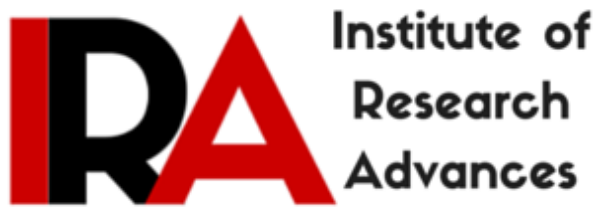

\title{
Pedagogical Content Knowledge (PCK) of Geography Teachers' and its Effect on Self- efficacy and Teacher Effectiveness in West Bengal, India
}

\author{
Anujit Patra $^{1 \#}$ \& Abhijit Guha ${ }^{2}$ \\ ${ }^{1}$ Research Scholar, Ramakrishna Mission Sikshanamandira (SVCMDRES), \\ Belur Math, Howrah, West Bengal, India. \\ ${ }^{2}$ Associate Professor, Ramakrishna Mission Sikshanamandira, Belur Math, \\ Howrah, West Bengal, India.
}

\#Corresponding author.

Type of Review: Peer Reviewed.

DOI: http://dx.doi.org/10.21013/jems.v6.n3.p2

\section{How to cite this paper:}

Patra, A., \& Guha, A. (2017). Pedagogical Content Knowledge (PCK) of Geography Teachers' and its Effect on Self-efficacy and Teacher Effectiveness in West Bengal, India. IRA International Journal of Education and Multidisciplinary Studies (ISSN 2455-2526), 6(3), 218-230. doi:http://dx.doi.org/10.21013/jems.v6.n3.p2

(C) Institute of Research Advances

(cc) EY-NC

This work is licensed under a Creative Commons Attribution-Non Commercial 4.0 International License subject to proper citation to the publication source of the work.

Disclaimer: The scholarly papers as reviewed and published by the Institute of Research Advances (IRA) are the views and opinions of their respective authors and are not the views or opinions of the IRA. The IRA disclaims of any harm or loss caused due to the published content to any party. 


\section{ABSTRACT}

The present study is concerned with the subject of Geography and its teachers in secondary school. The objective was to find out the status of pedagogical content knowledge (PCK) in Geography teachers and also its effect on Self-efficacy and Teacher effectiveness together. For conducting this study descriptive survey method was employed. The data was collected from 401 Geography teachers of secondary schools of West Bengal. The data was analyzed through SPSS 21. The MANOVA result led to reject the null hypothesis at 0.05 level of significance that there would be no significant multivariate effect for the combined dependent variables of self-efficacy and teacher effectiveness in respect of teachers' level of PCK in geography with Wilks' Lambda (i.e. Exact Statistic) value of .970, Pillai's Trace value of .030, Hotelling's Trace value of .031 and Roy's Largest Root value of .031. All the ' $p$ ' values were less than .05. Post hoc test showed that teachers with high level of PCK in Geography were significantly different from the teachers having moderate and low levels of PCK in geography in their self-efficacy. On the other hand, teachers with high level of PCK were significantly different from the teachers having low levels of PCK in geography in teacher effectiveness. Study also revealed that, teachers self-efficacy is positively related with teacher effectiveness in geography teaching.

Keywords: Pedagogical Content Knowledge, Self-efficacy, Teacher effectiveness, Geography teachers.

\section{INTRODUCTION:}

In the learner oriented modern teaching learning system, the teaching must facilitate learning and student can learn spontaneously. Teacher value is much important issue for shaping of student achievement. For this purpose, teacher has to play a vital role. He has to be equipped with his subject (content) knowledge and also to be competent enough to teach (pedagogy) his subject knowledge to the students. According to Shulman, pedagogical content knowledge (PCK) as a special amalgamation of content and pedagogy that is especially the area of teachers, their own special form of professional understanding. PCK is a characteristic of teacher knowledge of how to teach the subject matter. The term pedagogical content knowledge is widely discussed in teacher education program in West Bengal, India. PCK is an integrated knowledge of a specific content and how to teach it $[20,21]$. If a teacher possesses good PCK in his subject it is expected that it will influence his belief in self with respect to his efficacy in teaching and his effectiveness in teaching [4]. PCK is defined as a construct that includes both teachers' understanding and enactment of those things that teachers do. The professional experience (execution of PCK) and individual features (efficacy) of teachers has played a significant result on the teaching learning process in the classroom. Selfefficacy beliefs and Pedagogy Content Knowledge (PCK) affect teaching qualification and sustainability of pre-service and in-service teachers, so that the bilateral interaction of self-efficacy and PCK needs to be studied in order to be a guide in regulating the process of education or training teachers [7].

Teacher efficacy can be defined as a teacher's knowledge of self in terms of his or her own capability in teaching for a particular subject. The effect of teacher efficacy on teaching performance is recognized on the grounds of the social cognitive theory [6]. Elementary science teachers' PCK positively predicts students' achievement [13]. The positive correlations between teacher pedagogical content knowledge and student achievement provide authentication that an effective teacher could create good results in the children of middle school [14]. The increase in the contents of pedagogical knowledge resulted in changed pedagogical approaches, enhanced teacher student interaction, refinement of appropriate learning outcomes, critical decision making, improved teacher confidence, and enhanced student learning [12]. Effective teachers produced better performing students but that, not the only determinant of students' academic achievement [2]. Found significant difference in PCK of mathematics teacher in relation to qualification and experience, like teachers having higher qualifications and teaching experience found having better PCK and classroom teaching [16].

Research has found relationship between teacher knowledge (PCK) and teacher effectiveness. Self-efficacy is a critical component of effective teaching and can increase student achievement, it considered as a promoter of a teacher's movement from understanding to action [10]. 
In-service teachers' efficacy levels can be confidently forced by increased in content-specific pedagogical emphasis [22]. Teachers' knowledge of subject matter, attitude to work and teaching skills has a significant relationship on students' academic performance [1]. Higher teacher efficacy is related to higher student achievement and motivation, higher teacher retention and professional commitment, and more willingness to try new innovations and technologies. Teacher's sense of selfefficacy has been consistently recognized as an important attribute of effective teaching and has been positively correlated to teacher and student outcomes [23]. Teachers' self-efficacy made a significant contribution to the prediction of students' motivation to learn subject [17].

Student did differ in achievement of subject due to high or low teaching effectiveness of teachers. Significant correlation has been established between teacher competency and teaching effectiveness which signifies that, teacher competency factors related to teaching effectiveness [5]. Teachers in the latter stages of their career had different beliefs about their ability to perform important teaching activities that help pupils to learn. Consequently, it appears that teachers with extensive experience are better prepared for day-to-day teaching practice [19].

Based on the literature review, researchers found that, there were different studies conducted separately for self-efficacy and teacher effectiveness in respect of teachers' pedagogical content knowledge in different subjects at the school level, but there has been little done in the subject geography. This paper aims to describe the combined effect of PCK on self-efficacy and teachers effectiveness in the geography teaching at Bengali medium schools of West Bengal, India.

\section{HYPOTHESIS:}

Ho: There will no significant multivariate effect for the combined dependent variables of selfefficacy and teacher effectiveness in respect of teachers' level of PCK in geography.

\section{METHODOLOGY:}

The study was conducted through descriptive survey. Variables: Major variables of the study were (i) Pedagogical Content Knowledge (PCK) (ii) Self- Efficacy (iii) Teacher effectiveness. Population: The geography teachers who engaged in secondary and higher secondary schools, affiliated by W.B.B.S.E. only considered as the population of the present study. Sample: 401 geography teachers were randomly selected from different districts of west Bengal. Tools: Present researchers had used three types of tools; one was self made and standardized PCK Measuring Tool (PCKMT) to measure the teachers' PCK towards teaching of geography subject in Bengali medium school. Second was Self-efficacy scale (SES) constructed and validated by Dr. Arun Kumar Singh and Dr. Shruti Narin, published by National Psychological Corporation, Agra, India. Third scale was Teacher Effectiveness Scale (TES) constructed and validated by Dr. (Mrs.) Umme Kulsum, which also published by National Psychological Corporation, Agra, India. Procedure: Quantitative data were analyzed through SPSS 21.0 and MANOVA was used to study the effect of PCK on self-efficacy and teacher effectiveness together.

\section{RESULTS:}

\subsection{Preliminary Analysis:}

At first the Multivariate output describes the factors involved in the analysis. Those are labeled between-subject factors (Table.1), this was appropriate because the High, Moderate and Low PCK group were studied in the sample. With the help of obtained raw scores through PCK measuring tool, Total sample (401) has been grouped in to three separate levels, i.e. Low $(\mathrm{N}=135)$, Moderate $(\mathrm{N}=162)$, High $(\mathrm{N}=104)$ on the basis of the equal percentile scores i.e. nearly 33.33 percent $(\%)$ shows in the table: 1. Table: 2 shows an initial description of the factor wise dependent variables. This table contains the overall and group means and standard deviations for each dependent variable (Self-efficacy i.e. 76.73 and Teacher effectiveness i.e. 447.77) in order. It was understandable from 
the means that, the group with high PCK has the mean score on self-efficacy was 78.33. The group with moderate PCK has the mean score on self-efficacy is 76.58 and the group with low PCK has the mean score on self-efficacy was 75.69. On observation it was seen that, there were group wise mean differences in self-efficacy. As well as in respect of Teacher Effectiveness, the group with high PCK has the mean score on teacher effectiveness was 461.87. The group with moderate PCK has the mean score on teacher effectiveness was 447.89 and the group with low PCK has the mean score on teacher effectiveness was 436.76 . On observation it was seen that, there were group wise mean differences in teacher effectiveness also.

\subsection{Assumptions Testing:}

(i) Sample Size: The size of sample was 401 school teachers, who were engaged to teach geography, randomly selected from Secondary schools from different Districts of West Bengal. Having of large sample always helps to away with violations of the other assumptions (e.g. Normality) [18]. In this study (Table: 2) Descriptive Statistics shows the data pattern with satisfied the assumption.

(ii) Normality and Outliers: Before using multivariate test researcher also tested the assumption concerning with the normality and outliers of data. Without these two assumptions test of MANOVA could not significant because MANOVA is much sensitive to outliers [18]. In this study Mahalonabis distance used to check the normality, which was also helpful to identify any outliers. Table 3 ; shows that, in the row labeled Mahal. Distance corresponding with the column marked Maximum, the obtained value was 13.009 which was less than the critical value 13.82 (Table 4). Therefore researchers have satisfied with the assumption that, there were no considerable multivariate outliers. Assumptions concerning to the multivariate normality also acceptable.

(iii) Linearity: This assumption refers to the existence of straight line relationship between each pair of dependent variables. In this study the researcher tried to find out the presence of straight line relationship between each pair of dependent variable. To check linearity, matrix of scatter plots (Fig. 1) used between each pair of variables, separately for PCK group (High, Moderate and Low). These plots did not show any evidence of non-linearity, so the assumption of linearity was satisfied.

(iv) Multicollinearity: MANOVA works best if the dependent variables were moderately correlated. It also sensitive with highly correlated dependent variables [18]. In this study the ' $r$ ' value between self-efficacy and teacher effectiveness was .247 , which was less than .8 (strong relation). Therefore the assumption concerning with multicollinearity was satisfied.

(v) Homogeneity of variance-covariance matrices: Analysis (Table 6) Shows there was homogeneity of variance covariance matrices because the significance value $\mathrm{p}$ was $0.292(\mathrm{p}>.05)$. That means the box's test indicated no significant difference across the groups and the assumption was tenable.

(vi) Homogeneity of Variances: Table 7; indicates that, there was homogeneity across groups variance of self-efficacy and teacher effectiveness of geography teachers, because in the Sig. column, for both the self-efficacy was .056 ( $p>.05)$ and the teacher effectiveness was .767 ( $p>.05)$, so researcher can say that, there was no violations the assumption of equality of error variance for both variables, i.e. Self-efficacy and Teacher Effectiveness.

\subsection{Multivariate Outcome:}

After satisfying the assumptions multivariate analyses can make a significant result, (Table 8.). The multivariate tests of significance will indicate whether there were statistically significant differences among the group of PCK (i.e. High, Moderate, Low) on a linear combination of dependent variables (i.e. Self-Efficacy and Teacher Effectiveness). There are a number of statistics to select from Wilks' Lambda, Hotelling's Trace, Pillai's Trace. One of the most frequently reported statistics is Wilkis' Lambda (Pallant, 2010, p. 294). It also used when the independent variable has more than two groups [15]. Here analysis (Table 8) shows Wilks' Lambda (i.e. Exact Statistic) value of .970, with a significance value of .015 , Pillai's Trace value of .030 with a significance value of .016 , Hotelling's 
Trace value of .031 with a significance value of .015 and Roy's Largest Root value of .031 with a significance value of .002. All the ' $p$ ' values were less than .05; therefore it was concluded that, for the PCK factor (i.e. High, Moderate and Low), there were statistically significant differences in the combined dependent variables of self-efficacy and teacher effectiveness. Therefore, there was a significant multivariate effect for the combined dependent variables of self-efficacy and teacher effectiveness in respect of group of PCK (High, Moderate and Low).

\section{4: Univariate Outcome:}

From the above discussion it was clear that, the Geography teachers' PCK had a significant combined effect on their self-efficacy and effectiveness. The nature of that effect was not comprehensible from the multivariate test statistic [8]. This test tells not about which groups differed from which and nothing whether the effect of PCK was on self-efficacy, teacher effectiveness, or a combination of both. To determine the nature of the effect researchers used univariate tests.

In the table 9; the third set of values in a row labeled with PCK as independent value researcher found both the dependent variables listed, with their associated univariate F, df and Sig. values. It was found from the Sig column that, both the dependent variables self-efficacy $(p=.012)$ and teacher effectiveness $(\mathrm{p}=.043)$ recorded with significant value $(\mathrm{p}<.05)$. In this study significant difference were observed between High, Moderate and Low level of PCK group in teachers' self-efficacy as well as teacher effectiveness. Table 9; also shows that, both dependent variables ( Self-efficacy and Teacher effectiveness) differed significantly in respect of the independent variable (Groups_PCK): Self-Efficacy; $\mathrm{F}(2,398)=4.491, \mathrm{p}=.012$; Teacher Effectiveness; $\mathrm{F}=3.163, \mathrm{p}=.043$.

(i) Effect size: The impact of PCK levels of teachers on their self-efficacy and teacher effectiveness evaluated using the effect size statistic provided in the column i.e. Partial Eta Squared [18], which represents the proportion of the variance in the dependent variables that can be explained by the independent variable (Group_PCK). In this study for self-efficacy the value was 0.022 , and for teacher effectiveness the value was .016, both were considered quite a small effect. This represents only 2.2 per cent of the variance in self-efficacy and 1.6 per cent of the variance in teacher effectiveness explained by PCK.

(ii) Observed Power: Here power means the probability of perfectly rejecting the null hypothesis. The power of the interaction effect was .766 for self-efficacy and .605 for teacher effectiveness. If the study were to be replicated 100 times it could correctly reject the null hypothesis on self-efficacy $76.6 \%$ and on $60.5 \%$ of those replications.

\subsection{Post Hoc Test:}

Follow-up univariate analyses was necessary due to the presence of three levels in the dependent variable (i.e. Group_PCK) to recognize where the significance difference lie [18]. From the table 10; which contains multiple comparisons across the GROUP_PCK with the help of most liberal, Fisher's LSD post hoc test. This suggested teachers had high level of PCK were significantly more selfefficacious than the teachers had moderate and low levels of PCK in geography. On the other hand teachers had high level of PCK were significantly more effective than only the teachers had low levels of PCK in geography.

\section{FINDINGS AND DISCUSSIONS:}

A one-way between groups multivariate analysis of variance was performed to investigate impact of Pedagogical Content Knowledge (PCK) difference in geography teachers. Two dependent variables were used: self efficacy scores and teacher effectiveness scores. The independent variable was levels of PCK (i.e. High, Moderate, and Low) of geography teachers. Preliminary assumption testing was conducted to check for linearity, multivariate normality and outliers, homogeneity of variancecovariance matrices, and multicollinearity, with no serious violations noted. There was a statistically significance difference across the PCK groups (High, Moderate and Low) on the combined dependent variables, $\mathrm{F}(4,794)=3.096, \mathrm{p}=.015(\mathrm{p}<.05)$; Wilks' Lambda $=.970$; partial eta squared $=.015$. When the results for the dependent variables were considered separately, both differences reached to statistical significance, using the alpha level .05 , was self-efficacy, $F(2,398)=4.491$, p= 
$.012(\mathrm{p}<.05)$; partial eta squared $=.022$ and teacher effectiveness, $\mathrm{F}(2,398)=3.163, \mathrm{p}=.043(\mathrm{p}<$ $.05)$; partial eta squared $=.016$. Values of the mean scores indicated that, teachers having high PCK slightly higher levels of self-efficacy than teachers having moderate and low PCK in geography. Similar result recorded by $[3,4,11]$. On the other hand the mean scores also indicated that, teachers having high PCK slightly higher levels of teacher effectiveness than teachers having low PCK in geography $[4,12,13]$. There was significant multivariate effect of PCK for the combined dependent variables of self-efficacy and teacher effectiveness of geography teachers. Study also found that, selfefficacy and teacher effectiveness are related to each other positively, which is supported by $[4,10$, 23].

\section{CONCLUSION:}

The study is significant in that, it will help the geography teachers in understanding the function of PCK in their teaching process as a major factor. Through this study the teachers of geography will able to realize the importance of PCK in developing self-efficacy and increasing their effectiveness. It is said that geography teaches' self-efficacy and effectiveness is closely related together. So they should able to improve their students' academic achievements. The study might also helpful to increase consciousness among different authorities are engaged to train both pre-service and in service programme for geography teachers in West Bengal, India. The teacher educator also realizes the need to discuss PCK and its allied matter with more concentration to make trainees' more efficacious and effective.

\section{References:}

[1] Adediwura, A. A.; Tayo, Bada, (2007) Perception of Teachers' Knowledge, Attitude and Teaching Skills as Predictor of Academic Performance in Nigerian Secondary Schools, Educational Research and Reviews, v2 n7 p165-171 Jul 2007, Retrieved from, https://eric.ed.gov/?id=EJ900163

[2] Agharuwhe A. Akiri, (2013). Effects of Teachers' Effectiveness on Students' Academic Performance in Public Secondary Schools; Delta State - Nigeria, Journal of Educational and Social Research, MCSER Publishing, Rome-Italy, Vol. 3 No. 3, ISSN: 2239-978X E-ISSN: 2240-0524, Doi:10.5901/jesr.2013.v3n3p105

[3] Aina J. K., Olanipekun, S. S.(2015). A Review of Teacher Self-Efficacy, Pedagogical Content Knowledge (PCK) and Out-of-Field Teaching: Focussing on Nigerian Teachers. International Journal of Elementary Education. Vol. 4, No. 3, pp. 80-85. doi: 10.11648/j.ijeedu.20150403.15

[4] Audrey M. M., (2009). Teacher Efficacy in Geography: A Mixed Methods Study of Formal and Informal Teacher Education. San Marcos, Texas. Retrived from, https://digital.library.txstate.edu/handle/10877/4572

[5] Banerjee, S., Das, N. and Mohanty, A. (2014), Impact of Teacher Competence and Teaching Effectiveness on Students' Achievement in Life Science Subject at the Upper Primary Stage, Journal of Indian Education, Vol-XXXIX, No-4.pp. 29-48

[6] Bandura, A. (1977). Self-efficacy: Toward a unifying theory of behavioral change. Psychological Review, 84(2), 191-215. Retrived from, https://www.uky.edu/ eushe2/Bandura/Bandura1977PR.pdf

[7] Duschl, R. A. (1983). The elementary level science methods course: breeding ground of apprehension toward science: a case study. J. Res. Sci. Teaching 20(8): 745-754, Retrived from, http://onlinelibrary.wiley.com/doi/10.1002/tea.3660200805/pdf

[8] Field, A. (2009). Discovering Statistics Using SPSS. Sage pub. London. pp. 608-615. Retrived from, www.soc.univ.kiev.ua/.../andy-field-discovering-statistics- using-spss-third-edition$2009 \ldots$

[9] Gail V. B. (2004). Self-Efficacy and Teaching Effectiveness. South Carolina. Retrived from, https://pdfs.semanticscholar.org/7212/20c06a842f464e7ecc194e97b3f35c585204.pdf 
[10] Gibson, S. and Dembo, M. H., Teacher efficacy: A construct validation. Journal of Educational Psychology, Vol 76(4), Aug 1984, 569-582. http://dx.doi.org/10.1037/0022-0663.76.4.569

[11] Hartadiyati, E. WH, and Sutikno (2015), Self-Efficacy As Affective Domain Of Pedagogy Content Knowledge (PCK) : The Implications for Pre-Service and In-Service Teachers in Science Teaching, International Journal of Education and Research, Vol. 3 No. 1, pp. 391397, Retrived from, www.ijern.com/journal/2015/January-2015/32.pdf

[12] Jones, A. and Moreland, J. (2004). Enhancing Practicing Primary School Teachers' Pedagogical Content Knowledge in Technology, International Journal of Technology and Design Education, May 2004, DOI: 10.1023/B:ITDE.0000026513.48316.39, Retrieved from, https://www.researchgate.net/publication/226950985

[13] Lange, K., Kleickmann, T., Moller, K. (2012), Elementary Teachers' Pedagogical Content Knowledge and Student Achievement In Science Education, In C. Bruguiere, A. Tiberghien and O. Clement (Eds), Science Learning and Citizenship. Proceedings of the ninth ESERA- Conference, 2011.Lyon. Retrieved from, http://www.unimuenster.de/imperia/md/content/didaktik_des_sachunterrichts/dokumente/literaturm oeller/el ementary_teachers_pedagogical_content_knowledge....pdf

[14] Lenhart, S. T. (2010), The Effect of Teacher Pedagogical Content Knowledge and the Instruction of Middle School Geometry. Retrieved from,citeseerx.ist.psu.edu/viewdoc/download? doi=10.1.1.905.5747\&rep=rep1...

[15] Mayer, A. (2013). Introduction to Statistics and SPSS in Psychology. Pearson Education Ltd. Edinburg. pp. 317-334.

[16] Mohalik R. (2013), Pedagogical Content Knowledge and Classroom Teaching of Mathematics Teachers at the Secondary Level, Journal of Indian Education. Vol-XXXVIII, Number-4, pp. $15-24$.

[17] Ngunjiri, M. \& Singh, P. N. (2012). The relationship between Students' Motivation to Learn and Teachers' Self-efficacy in Mathematics among Secondary School Students in Kenya. Journal of Indian Education, vol-XXXVIII, no-2 pp.81-88.

[18] Pallant. J. (2010). SPSS Survival Manual. Mac Graw Hill, USA. pp. 283-296.

[19] Samuelsson, M., Samuelsson, J. and Autio, O. (2015), Tracing patterns of sloyd teachers' efficacy beliefs at different stages of their professional careers, Techne Series A, 22(1), pp. 30-43, Retrieved

from, https://journals.hioa.no/index.php/techneA/article/download/819/1158

[20] Shulman, L. S. (1986), Those Who Understand: Knowledge Growth and Teaching, Educational Researcher, Vol-15, No-2, pp. 4-14. Retrieved from http://www.jstor.org/journals/aera.html.

[21] Shulman, L. S. (1987), Knowledge \& Teaching : Foundations of the New Reform, Havard Educational Review, Vol- 57, No-1, pp. 1-21. Retrieved from http://links.jstor.org/sici?sici=0013189X\%28198602\%2915\%3A2\%3C4\%3ATWUKGI\%3E2.0.CO\%3B2-X

[22] Swackhamer, L. E., Koellner, K., Basile, C. \& Doris Kimbrough, (2009), Increasing the SelfEfficacy of Inservice Teachers through Content Knowledge, Teacher Education Quarterly, Spring 2009, pp. 63-78, Retrieved from, files.eric.ed.gov/fulltext/EJ857476.pdf

[23] Tschannen-Moran, M., Woolfok-Hoy, A., and Hoy, W. K. (1998). Teacher efficacy: Its meaning and measure. Review of Educational Research, 68(2), pp. 202-248. 
Tables \& Figures

\begin{tabular}{|c|c|c|c|c|}
\hline & & Value Label & $\mathrm{N}$ & $\%$ \\
\hline \multirow{3}{*}{ GROUP_PCK } & 1 & LOW & 135 & 33.66 \\
\hline & 2 & MODERATE & 162 & 40.40 \\
\hline & 3 & HIGH & 104 & 25.94 \\
\hline \multicolumn{3}{|c|}{ TOTAL } & 401 & 100 \\
\hline
\end{tabular}

Table.2: Descriptive Statistics

\begin{tabular}{|c|c|c|c|c|}
\hline $\begin{array}{c}\text { DEPENDENT } \\
\text { VARIABLES }\end{array}$ & GROUP_PCK & Mean & $\begin{array}{c}\text { Std. } \\
\text { Deviation }\end{array}$ & $\mathrm{N}$ \\
\hline \multirow{4}{*}{ SELF-EFFICACY } & LOW & 75.69 & 7.33 & 135 \\
\cline { 2 - 5 } & MODERATE & 76.58 & 6.81 & 162 \\
\cline { 2 - 5 } & HIGH & 78.33 & 6.01 & 104 \\
\cline { 2 - 5 } & Total & 76.73 & 6.86 & 401 \\
\hline \multirow{4}{*}{ TEACHER EFFECTIVENESS } & LOW & 436.76 & 77.82 & 135 \\
\cline { 2 - 5 } & MODERATE & 447.89 & 76.02 & 162 \\
\cline { 2 - 5 } & HIGH & 461.87 & 75.58 & 104 \\
\cline { 2 - 5 } & Total & 447.77 & 76.93 & 401 \\
\hline
\end{tabular}

\begin{tabular}{|c|c|c|c|c|c|}
\hline Table:3 Residuals Statistics $^{\mathrm{a}}$ & Minimum & Maximum & Mean & Std. Deviation & $\mathrm{N}$ \\
\hline Predicted Value & 1.55 & 2.24 & 1.92 & .132 & 401 \\
\hline Std. Predicted Value & -2.833 & 2.399 & .000 & 1.000 & 401 \\
\hline Standard Error of Predicted Value & .038 & .142 & .063 & .019 & 401 \\
\hline Adjusted Predicted Value & 1.56 & 2.26 & 1.92 & .132 & 401 \\
\hline Residual & -1.240 & 1.316 & .000 & .758 & 401 \\
\hline Std. Residual & -1.632 & 1.733 & .000 & .997 & 401 \\
\hline Stud. Residual & -1.646 & 1.747 & .000 & 1.001 & 401 \\
\hline Deleted Residual & -1.261 & 1.338 & .000 & .763 & 401 \\
\hline Stud. Deleted Residual & -1.650 & 1.752 & .000 & 1.002 & 401 \\
\hline Mahal. Distance & $\mathbf{. 0 0 3}$ & $\mathbf{1 3 . 0 0 9}$ & $\mathbf{1 . 9 9 5}$ & $\mathbf{1 . 8 9 2}$ & $\mathbf{4 0 1}$ \\
\hline Cook's Distance & .000 & .024 & .002 & .003 & 401 \\
\hline Centered Leverage Value & .000 & .033 & .005 & .005 & 401 \\
\hline a. Dependent Variable: GROUP_PCK & & & \\
\hline
\end{tabular}


Table: 4. Critical values for evaluating Mahalanobis distance values

\begin{tabular}{|l|l|l|l|l|l|l|l|l|l|}
\hline $\begin{array}{l}\text { Number of } \\
\text { Dependent } \\
\begin{array}{l}\text { Variables } \\
\text { Critical Value }\end{array}\end{array}$ & 2 & 3 & 4 & 5 & 6 & 7 & 8 & 9 & 10 \\
\cline { 2 - 8 } & 13.82 & 16.27 & 18.47 & 20.52 & 22.46 & 24.32 & 26.13 & 28.88 & 29.59 \\
\hline
\end{tabular}

Source: adapted from a Table in Pallant,(2010). P-288; originally from Pearson, E.S. and Hartley, H.O.(Eds) (1958). Biometrika Tables for statisticians (vol. 1, $2^{\text {nd }}$ edn). New York: Cambridge University Press.

\begin{tabular}{|c|c|c|c|}
\hline & & $\begin{array}{c}\text { SELF } \\
\text { EFFICACY }\end{array}$ & $\begin{array}{c}\text { TEACHER } \\
\text { EFFECTIVENESS }\end{array}$ \\
\hline \multirow{3}{*}{ SELF-EFFICACY } & Pearson Correlation & 1 & $.247 *$ \\
\hline & Sig. (2-tailed) & & .000 \\
\hline & $\mathrm{N}$ & 401 & 401 \\
\hline \multirow{3}{*}{$\begin{array}{c}\text { TEACHER } \\
\text { EFFECTIVENESS }\end{array}$} & Pearson Correlation & $.247 *$ & 1 \\
\hline & Sig. (2-tailed) & .000 & \\
\hline & $\mathrm{N}$ & 401 & 401 \\
\hline
\end{tabular}

Table: 6. Box's Test of Equality of Covariance Matrices ${ }^{a}$

\begin{tabular}{|c|c|}
\hline $\begin{array}{c}\text { Box's } \\
\mathrm{M}\end{array}$ & 7.382 \\
\hline $\mathrm{F}$ & 1.221 \\
\hline $\mathrm{df} 1$ & 6 \\
\hline df2 & 2029613.016 \\
\hline Sig. & .292 \\
\hline
\end{tabular}

Tests the null hypothesis that the observed covariance matrices of the dependent variables are equal across groups. ${ }^{\mathrm{a}}$

b. Design: Intercept + GROUP_PCK 


\begin{tabular}{|c|c|c|c|c|}
\hline \multicolumn{6}{|l|}{ Table: 7. Levene's Test of Equality of Error Variances ${ }^{\mathrm{a}}$} \\
\hline Dependent Variable & F & df1 & df2 & Sig. \\
\hline SELF EFFICACY & 2.902 & 2 & 398 & .056 \\
\hline TEACHER EFFECTIVENESS & .266 & 2 & 398 & .767 \\
\hline
\end{tabular}

Tests the null hypothesis that the error variance of the dependent variable is equal across groups. ${ }^{\mathrm{a}}$

b. Design: Intercept + GROUP_PCK

\begin{tabular}{|c|c|c|c|c|c|c|c|}
\hline \multicolumn{2}{|c|}{ Effect } & Value & $\mathrm{F}$ & Hypothesis df & Error df & Sig. & Partial \\
\hline \multirow{4}{*}{ Intercept } & Pillai's Trace & .993 & $26876.977^{\mathrm{b}}$ & 2.000 & 397.000 & .000 & .993 \\
\hline & Wilks' Lambda & .007 & $26876.977^{\mathrm{b}}$ & 2.000 & 397.000 & .000 & .993 \\
\hline & Hotelling's Trace & 135.400 & $26876.977^{b}$ & 2.000 & 397.000 & .000 & .993 \\
\hline & Roy's Largest Root & 135.400 & $26876.977^{\mathrm{b}}$ & 2.000 & 397.000 & .000 & .993 \\
\hline \multirow{4}{*}{ GROUP_PCK } & Pillai's Trace & .030 & 3.081 & 4.000 & 796.000 & .016 & .015 \\
\hline & Wilks' Lambda & .970 & $3.096^{\mathrm{b}}$ & 4.000 & 794.000 & .015 & .015 \\
\hline & Hotelling's Trace & .031 & 3.112 & 4.000 & 792.000 & .015 & .015 \\
\hline & Roy's Largest Root & .031 & $6.212^{\mathrm{c}}$ & 2.000 & 398.000 & .002 & .030 \\
\hline \multicolumn{8}{|c|}{$\begin{array}{l}\text { a. Design: Intercept + GROUP_PCK } \\
\text { b. Exact statistic } \\
\text { c. The statistic is an upper bound on F that yields a lower bound on the significance level. } \\
\text { d. Computed using alpha }=.05\end{array}$} \\
\hline
\end{tabular}


Table: 9. Tests of Between-Subjects Effects

\begin{tabular}{|c|c|c|c|c|c|c|c|c|}
\hline Source & Dependent Variable & $\begin{array}{l}\text { Type III Sum } \\
\text { of Squares }\end{array}$ & $\mathrm{df}$ & Mean Square & $\mathrm{F}$ & Sig. & $\begin{array}{l}\text { Partial } \\
\text { Eta } \\
\text { Squared }\end{array}$ & $\begin{array}{c}\text { Observed } \\
\text { Power }\end{array}$ \\
\hline \multirow[b]{2}{*}{$\begin{array}{c}\text { Corrected } \\
\text { Model }\end{array}$} & SELF EFFICACY & $415.174^{\mathrm{a}}$ & 2 & 207.587 & 4.491 & .012 & .022 & $.766^{\mathrm{a}}$ \\
\hline & $\begin{array}{c}\text { TEACHER } \\
\text { EFFECTIVENESS }\end{array}$ & $37042.916^{b}$ & 2 & 18521.458 & 3.163 & .043 & .016 & $.605^{\mathrm{b}}$ \\
\hline \multirow[b]{2}{*}{ Intercept } & SELF EFFICACY & 2292437.794 & 1 & 2292437.794 & 49593.772 & .000 & .992 & 1.000 \\
\hline & $\begin{array}{c}\text { TEACHER } \\
\text { EFFECTIVENESS }\end{array}$ & 78165094.039 & 1 & 78165094.039 & 13350.413 & .000 & .971 & 1.000 \\
\hline \multirow[b]{2}{*}{ GROUP_PCK } & SELF EFFICACY & 415.174 & 2 & 207.587 & 4.491 & .012 & .022 & .766 \\
\hline & $\begin{array}{c}\text { TEACHER } \\
\text { EFFECTIVENESS }\end{array}$ & 37042.916 & 2 & 18521.458 & 3.163 & .043 & .016 & .605 \\
\hline \multirow[b]{2}{*}{ Error } & SELF EFFICACY & 18397.275 & 398 & 46.224 & & & & \\
\hline & $\begin{array}{c}\text { TEACHER } \\
\text { EFFECTIVENESS }\end{array}$ & 2330243.049 & 398 & 5854.882 & & & & \\
\hline \multirow[b]{2}{*}{ Total } & SELF EFFICACY & 2379892.000 & 401 & & & & & \\
\hline & $\begin{array}{c}\text { TEACHER } \\
\text { EFFECTIVENESS }\end{array}$ & 82765388.000 & 401 & & & & & \\
\hline \multirow{2}{*}{$\begin{array}{l}\text { Corrected } \\
\text { Total }\end{array}$} & SELF EFFICACY & 18812.449 & 400 & & & & & \\
\hline & $\begin{array}{c}\text { TEACHER } \\
\text { EFFECTIVENESS }\end{array}$ & 2367285.965 & 400 & & & & & \\
\hline
\end{tabular}




\begin{tabular}{|c|c|c|c|c|c|}
\hline Dependent Variable & $\begin{array}{c}\text { (I) GROUP } \\
\text { PEDAGOGICAL } \\
\text { CONTENT } \\
\text { KNOWLEDGE }\end{array}$ & $\begin{array}{c}\text { (J) GROUP } \\
\text { PEDAGOGICAL } \\
\text { CONTENT } \\
\text { KNOWLEDGE }\end{array}$ & $\begin{array}{c}\text { Mean } \\
\text { Difference } \\
\text { (I-J) }\end{array}$ & $\begin{array}{l}\text { Std. } \\
\text { Error }\end{array}$ & Sig. \\
\hline \multirow{6}{*}{ SELF-EFFICACY } & \multirow{2}{*}{ LOW } & MODERATE & -.8914 & .79230 & .261 \\
\hline & & HIGH & $-2.6380^{*}$ & .88706 & .003 \\
\hline & \multirow{2}{*}{ MODERATE } & LOW & .8914 & .79230 & .261 \\
\hline & & HIGH & $-1.7467^{*}$ & .85428 & .042 \\
\hline & \multirow[b]{2}{*}{ HIGH } & LOW & $2.6380^{*}$ & .88706 & .003 \\
\hline & & MODERATE & $1.7467^{*}$ & .85428 & .042 \\
\hline \multirow{6}{*}{$\begin{array}{c}\text { TEACHER } \\
\text { EFFECTIVENESS }\end{array}$} & \multirow{2}{*}{ LOW } & MODERATE & -11.1333 & 8.91688 & .213 \\
\hline & & HIGH & $-25.1098^{*}$ & 9.98331 & .012 \\
\hline & \multirow{2}{*}{ MODERATE } & LOW & 11.1333 & 8.91688 & .213 \\
\hline & & HIGH & -13.9765 & 9.61448 & .147 \\
\hline & \multirow{2}{*}{ HIGH } & LOW & $25.1098^{*}$ & 9.98331 & .012 \\
\hline & & MODERATE & 13.9765 & 9.61448 & .147 \\
\hline $\begin{array}{l}\text { Based on observed } \mathrm{m} \\
\text { The error term is Me } \\
* \text {. The mean differen }\end{array}$ & $\begin{array}{l}\text { s. } \\
\text { Square (Error) } \\
\text { s significant at }\end{array}$ & $\begin{array}{l}882 . \\
\text { level. }\end{array}$ & & & \\
\hline
\end{tabular}


Fig.1; Linearity between Each Pair of Dependent Variables (S.E., T.E.) and GROUPS_PCK.
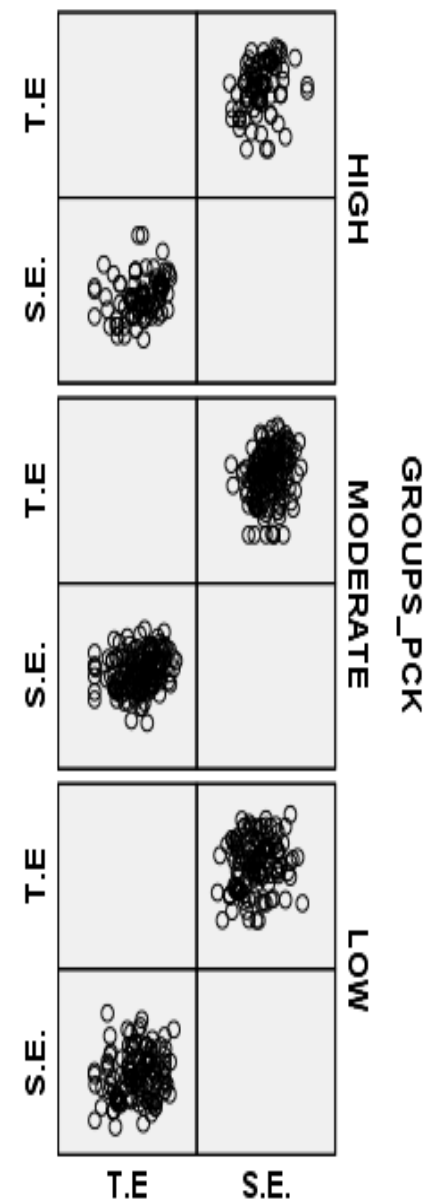

T.E.: Teacher Effectiveness, S.E.: Self-Efficacy, PCK_GROUP: High, Moderate and Low. 